\title{
Originals
}

\section{Genetic analysis of obesity-induced diabetes associated with a limited capacity to synthesize insulin in C57BL/KS mice: evicence for polygenic control}

\author{
K. Kaku ${ }^{1}$, M.Province ${ }^{2}$ and M.A.Permutt ${ }^{1}$ \\ ${ }^{1}$ Metabolism Division, Department of Internal Medicine, and \\ ${ }^{2}$ Division of Biostatistics, Washington University School of Medicine, St. Louis, Missouri, USA
}

\begin{abstract}
Summary. Expression of obesity-induced diabetes associated with the diabetes or $d b$ mutation in mice varies in inbred strains. This study utilized a genetic analysis to evaluate the number of genes responsible for the difference in diabetes responses between mice of the susceptible C57BL/KsJ (BL/Ks) and resistant $129 / \mathrm{J}$ inbred strains. $\mathrm{BL} / \mathrm{Ks}(d b /+)$ males and $129 / \mathrm{J}(+/+)$ females were bred to generate $F_{1}$ hybrids, and the $F_{1}$ females $(d b /+$ and $+/+$, distinguished by progeny testing) were backcrossed to $\mathrm{BL} / \mathrm{Ks}(d b /+)$ males. A total of 252 backcrossed males were obtained, of which 31 were $d b / d b$ and obese. While the plasma glucose of all the fed backcrossed mice was greater than $22 \mathrm{mmol} / \mathrm{l}$, the expression of diabetes varied considerably, as measured by fasting plasma glucose, fed plasma insulin, and pancreatic insulin and proinsulin mRNA content. That proinsulin mRNA content was a good indicator of diabetes severity and islet dysfunction was seen in the inverse correlation between proinsulin mRNA content and fasting plasma glucose $(r=0.69, p<0.001)$, and a
\end{abstract}

direct correlation between proinsulin mRNA and plasma insulin $(r=0.86, p<0.001)$, and pancreatic insulin content $(r=0.61, p<0.01)$. If a single gene were responsible for severe islet dysfunction, one-half of the backcrossed mice would develop low proinsulin $m R N A$ levels like the $B L / K s$ parent, and one-half would be resistant to islet destruction. Statistical evaluation (SKUMIX) of the distribution of these parameters in backcrossed mice rejected with a high degree of probability a bimodal distribution. Thus, it was concluded that while a dominant gene (or genes) is responsible for diabetic $(>22 \mathrm{mmol} / \mathrm{l})$ unfasted plasma glucose in all backcrossed mice, allelic differences at two or more genetic loci are responsible for the differences between the two strains in diabetes severity measured by fasting plasma glucose, pancreatic insulin, and proinsulin mRNA content.

Key words: $\mathrm{C} 57 \mathrm{BL} / \mathrm{KsJ} d b / d b$ mice, genetic analysis, proinsulin mRNA, polygenic control.
The diabetes $(d b)$ mutation on chromosome 4 occurred spontaneously in $\mathrm{C} 57 \mathrm{BL} / \mathrm{KsJ}(\mathrm{BL} / \mathrm{Ks})$ mice $[1,2]$. In the homozygous condition $(d b / d b)$, this mutation produces hyperphagia, progressive obesity, and insulin resistance. The initial adaptation to the insulin resistance is one of islet hyperplasia resulting in marked hyperinsulinaemia, but ultimately the islets develop B-cell necrosis, and the mice become insulinopoenic, severely hyperglycaemic and lose weight. The response to the obesity-induced insulin resistance of the $d b$ mutation in $\mathrm{BL} / \mathrm{Ks}$ mice, however, differs from that in other inbred strains, with a milder diabetes noted for example in C57BL/6J (BL/6) and 129/J mice [3-8]. The diabetes resistant strains appear to compensate for the insulin resistance by developing pronounced islet cell hyperplasia and hyperinsulinaemia without islet destruction.

In previous studies, $d b / d b$ mice of the diabetes susceptible $\mathrm{BL} / \mathrm{Ks}$ strain were observed with longitudinal measurements of proinsulin mRNA to assess insulin biosynthesis [9]. At five weeks of age, the $d b / d b$ mice had a four-fold increase in serum insulin and a comparable increase in proinsulin mRNA above that in the lean littermates. Progressive hyperglycaemia developed, and at 10 and 13 weeks a marked loss of insulin biosynthesis was demonstrated, as evidenced by parallel decreases in serum insulin and proinsulin mRNA. The measurements of proinsulin mRNA permitted a quantitative assessment of total B-cell function in vivo, and allowed estimation of changes in insulin synthesis that occurred with obesity and with age. The loss of insulin synthesis was related to a worsening of hyperglycaemia, and insufficient insulin synthetic capacity was associated with the ultimate development of severe diabetes.

In the present experiments, the number of background modifying genes responsible for determining a limited capacity to synthesize insulin has been assessed in $\mathrm{BL} / \mathrm{Ks}$ mice. The influence of genetic background on the expression of the $d b$ mutation in mice has been evaluated by Coleman and associates [10,11]. 


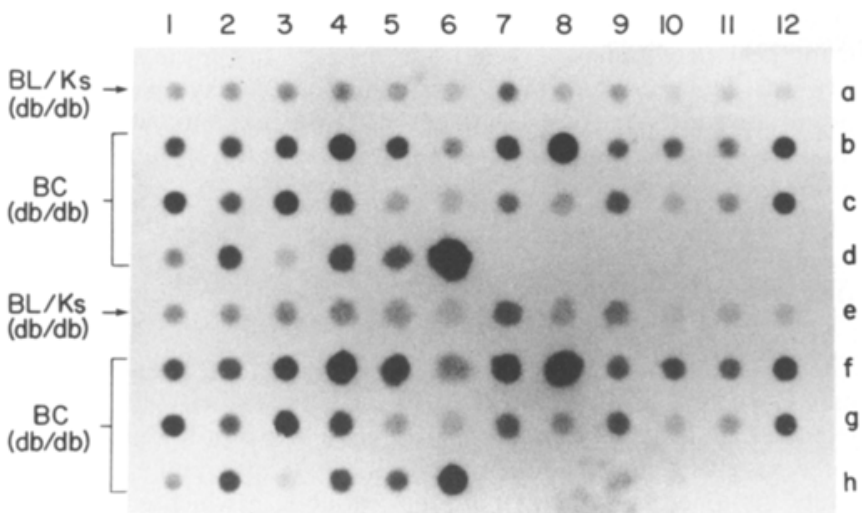

Fig. 1. Autoradiograph of dot-blot hybridization of pancreatic RNA with ${ }^{32} \mathrm{P}$-rat proinsulin (PI) cRNA demonstrating the relative concentration of proinsulin mRNA in total RNA in $d b / d b$ mice of the BL/Ks parental strain $(n=12)$ compared to that in $d b / d b$ backcross (BC) mice $(n=30)$ at the same age ( 14 weeks). The proinsulin mRNA concentration in $d b / d b$ backcross mice varied from $<1 \mathrm{ng}$ to $>20 \mathrm{ng} /$ pancreas, while the concentration in BL/Ks parental mice was $<7 \mathrm{ng}$ /pancreas. PI mRNA was measured in total pancreatic RNA $(10 \mu \mathrm{g})$ relative to a synthetic rat I proinsulin cRNA standard as described in Methods. Rows a-d are duplicated in rows $\mathrm{e}-\mathrm{h}$

Blood glucose, plasma insulin, and islet histology were assessed in $\mathrm{F}_{1}$ hybrids of the $\mathrm{BL} / \mathrm{Ks}$ and $\mathrm{BL} / 6$ strains and in backcrosses of $F_{1}$ hybrid mice to each parental strain. Lack of segregation of these parameters in the backcrossed $(\mathrm{BC})$ mice into two classes $\left(\mathrm{F}_{1}\right.$ like vs $\mathrm{BL} / \mathrm{Ks}$ or $\mathrm{BL} / 6$ like), led to the conclusion that expression of the diabetes syndrome was under multigenic control. Moreover, the genes responsible for the more severe diabetic syndrome of the $\mathrm{BL} / \mathrm{Ks}$ mice were recessive to those in the $\mathrm{BL} / 6$ genome. More recently, in the course of development of a BL/Ks.BL/6-H-2B congenic stock, Leiter et al. [12] reevaluated diabetes susceptibility in $\mathrm{BL} / \mathrm{Ks}$ and $\mathrm{BL} / 6$ strains. The results were surprisingly different from those initially reported, with all the $d b / d b$ mice of both the $F_{1}$ and $F_{2}$ generations exhibiting severe hyperglycaemia and atrophic islets. These results were difficult to explain, but consistent with multiple diabetes susceptibility genes in the $\mathrm{BL} / \mathrm{Ks}$ strains which now appeared to be dominant.

Because of the discrepancy of previous reports, crosses of mice of the $129 / \mathrm{J}$ inbred strain, previously shown to be resistant to obesity induced-diabetes associated with the $d b$ mutation $[7,8]$, with $\mathrm{KsJ}$ mice were evaluated. If a single gene were responsible for severe loss of proinsulin mRNA and diabetes in $\mathrm{BL} / \mathrm{Ks}$ mice, expression of the diabetes syndrome in $\mathrm{F}_{1}$ hybrid mice backcrossed to the $\mathrm{BL} / \mathrm{Ks}$ parental strain might segregate into diabetic and non-diabetic populations, defined by their capacity to synthesize insulin. This analysis has been completed, and the results are consistent with the interpretation that multiple genes regulate the expression of diabetes and the capacity to synthesize insulin following induction of obesity by the $d b$ mutation in $\mathrm{BL} / \mathrm{Ks}$ mice.

\section{Materials and methods}

\section{Animals}

Male C57BL/KsJ mice, heterozygous for the $d b$ mutation $(d b /+)$, and female $129 / \mathrm{J}$ mice, homozygous non-diabetic at the $d b$ locus $(+/+)$, were obtained from the Jackson Laboratories (Bar Harbor, Me, USA) after weaning at roughly four weeks of age. Mice were given free access to tap water and chow (Purina Rodent Chow, Ralston Purina, St.Louis, Mo, USA) throughout the experiment.

\section{Breeding protocol}

$\mathrm{BL} / \mathrm{Ks}(d b /+)$ male mice were crossed with $129 / \mathrm{J}(+/+)$ females. Half of the $F_{1}$ mice would be heterozygous for the $d b$ mutation $(d b /+)$ and the other half would be homozygous non-diabetic $(+/+)$. The $F_{1}$ female mice $(d b /+$ and $+/+)$ were backcrossed with $\mathrm{BL} / \mathrm{Ks}(d b /+)$ males, and the $\mathrm{BC}$ mice would be expected to produce $d b / d b, d b /+$, and $+/+$ progeny in the ratio $1 / 8: 4 / 8: 3 / 8$. The homozygous diabetic BC mice $(d b / d b)$, determined by the progeny test for obesity and characteristic shape at five weeks of age [1-3] were maintained to measure plasma glucose and insulin, pancreatic insulin and pancreatic proinsulin mRNA contents. Male mice were analysed exclusively to avoid gender differences in the development of diabetes $[5,15]$. By breeding $\mathrm{BL} / \mathrm{Ks}$ males $(\mathrm{db} /+)$ with $129 / \mathbf{J}$ females $(+/+)$, and then backcrossing $F_{1}$ females with parental $\mathrm{BL} / \mathrm{Ks}$ males, all of the male $\mathrm{BC}$ mice had only the $\mathrm{BL} / \mathrm{Ks}$ Y-chromosome.

\section{Measurements of plasma glucose and insulin concentrations}

Whole blood $(300 \mu 1)$ was collected between 09.00 and 11.00 hours in the fed or fasted state $(18 \mathrm{~h})$ from the retro-orbital sinus of ether anaesthetized animals at 5,10 , and 14 weeks of age using a heparin-treated microhaematocrit capillary tube. Plasma glucose was measured using the Beckman Glucose Analyzer II, and plasma insulin was assayed by a double antibody radioimmunoassay (RIA) method with purified rat insulin standards (Novo Inc., Copenhagen, Denmark). All assays were done in duplicate.

\section{Determination of pancreatic insulin}

Mice were killed in the fed state at 14 weeks of age. Animals were injected intraperitoneally with $15 \mathrm{mg}$ pentobarbital sodium $/ 100 \mathrm{~g}$ body weight. Before cardiorespiratory arrest, the abdomen and thorax were dissected, then the pancreas was excised. Pancreatic tissue was rapidly cut into small pieces and these were divided into two aliquots of approximately equal weight, weighed, then one was homogenized immediately for isolation of pancreatic RNA, and the other was frozen in liquid nitrogen. The frozen aliquots of pancreas for insulin determination were stored at $-80^{\circ} \mathrm{C}$ until all specimens were available; then each specimen was homogenized in $2 \mathrm{ml}$ of acid ethanol $(75 \%$ ethanol, $0.15 \mathrm{~mol} / 1 \mathrm{HCl})$ with a Polytron homogenizer (Brinkman, Westburg, NY, USA). Homogenates were incubated at $4^{\circ} \mathrm{C}$ for $48 \mathrm{~h}$, then the suspension was centrifuged for $10 \mathrm{~min}$ at $12,000 \times \mathrm{g}$. The pellet was resuspended in $1 \mathrm{ml}$ of acid ethanol. After incubation at $4^{\circ} \mathrm{C}$ for $24 \mathrm{~h}$, the suspension was centrifuged as mentioned above. The second supernatant was pooled with the first and diluted 1:3000 in $0.1 \mathrm{~mol} / 1$ phosphate-buffered saline solution, pH 7.4., containing $0.25 \%$ bovine serum albumin. Insulin was measured by double antibody RIA. All assays were performed in duplicate. 

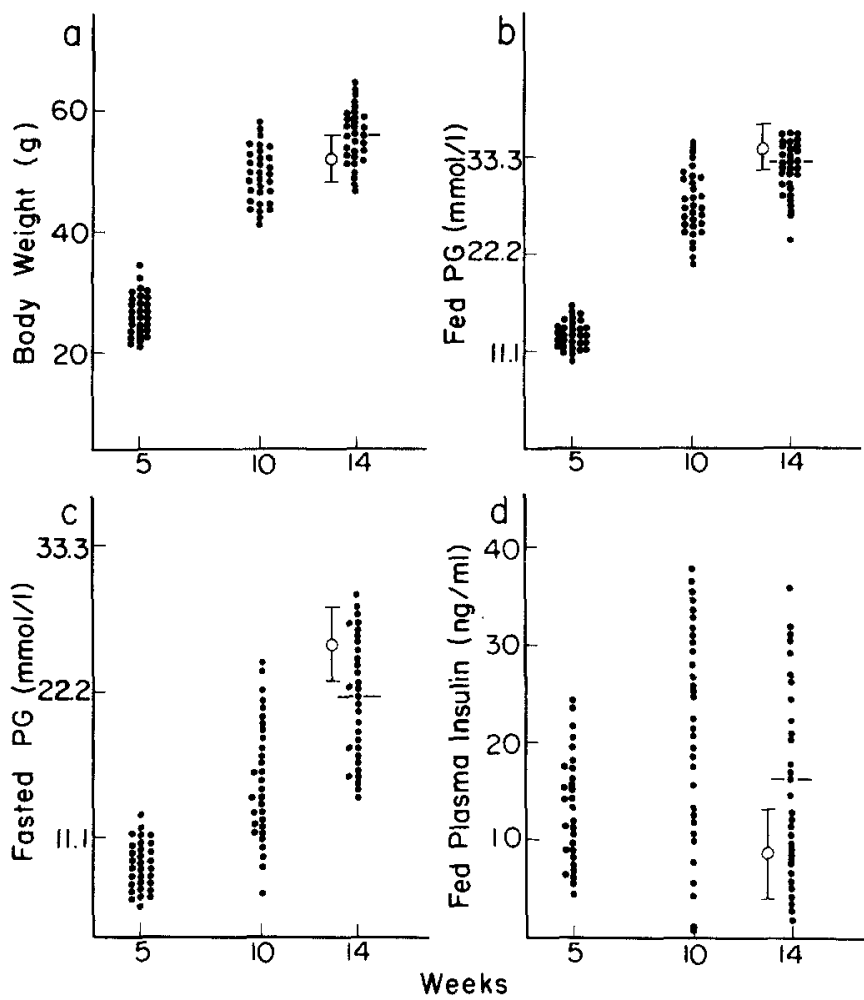

Fig. 2. a Body weight, b fed plasma glucose (PG), c fasted $P G$, and d fed plasma insulin were determined as described in the Methods on $31 \mathrm{BC}$ male $d b / d b$ mice which were obtained from 252 progeny of $\mathrm{BL} / \mathrm{Ks}(d b /+) \times \mathrm{F}_{1}(\mathrm{BL} / \mathrm{Ks}[d b /+] \mathrm{X} 129 \mathrm{~J}[+/+\mathrm{D})$. The open circles and error bars represent the mean \pm S. D. of determinations of $d b / d b$ mice $(n=12)$ of the $\mathrm{BL} / \mathrm{Ks}$ parental strain for comparison at 14 weeks of age. The mean of the values in backcross mice at 14 weeks of age is indicated by the dotted horizontal lines

\section{Determination of pancreatic proinsulin $m R N A$}

Immediately after dissection, aliquots of pancreas were homogenized at high speed with the Polytron homogenizer in $2.5 \mathrm{ml}$ of $4 \mathrm{~mol} / 1$ guanidine thiocyanate solution containing $25 \mu \mathrm{l}$ of 2 -mercaptoethanol. RNA was purified by serial ethanol precipitation using the method described previously [9]. Total RNA yield was assessed by measuring optical density at $260 \mathrm{~nm}$, and purity of RNA was estimated from ratios of absorbance at 260 and $280 \mathrm{~nm}$; in all samples the ratios were $>2.05$. Intactness of RNA was assessed by electrophoresing $5 \mu \mathrm{g}$ aliquots of total RNA on $1.2 \%$ agarose formaldehyde gels as described [9]. Integrity was assessed in stained gels by a ratio of $28 \mathrm{~S}$ and $18 \mathrm{~S}$ rRNA bands greater than 1.0 in all samples.

Pancreatic RNA $(10 \mu \mathrm{g})$ in $15 \mu \mathrm{l}$ of sterile water containing $6.7 \%$ formaldehyde and $10 \mathrm{X} \mathrm{SSC}$ was denatured at $50^{\circ} \mathrm{C}$ for $15 \mathrm{~min}$, and applied directly to nylon membranes (Biotrans, ICN Biomedicals, Inc., Cleveland, Oh, USA) using a 96-well Hybri-Dot apparatus (Bethesda Research Laboratories, Gaithersburg, Md, USA). RNA from all mice was applied to a single membrane in duplicate. Serial dilutions of an unlabelled mouse proinsulin 1 cRNA (synthetic 311 bases) and $20 \mu \mathrm{g}$ aliquots of mouse liver and kidney RNA were also applied. Blots were air dried and baked at $80^{\circ} \mathrm{C}$ for $2 \mathrm{~h}$.

Proinsulin mRNA was assessed by its hybridization to the mouse proinsulin I single-stranded cRNA labelled with $\alpha^{32}$ P-CTP ( $>$ $600 \mathrm{Ci} / \mathrm{mmole}$, Amersham Corporation, Arlington Heights, Ill, USA) with a kit according to the manufacturer's protocol (Riboprobe Gemini System, Promega, Madison, Wis, USA). Blots were exposed to Kodak XAR-5 film overnight at $-70^{\circ} \mathrm{C}$ with an intensifying screen (Fig. 1). Densitometric analysis of autoradiographs was made with a
Hoefer GS300 scanning densitometer (San Francisco, Calif, USA) utilizing peak height to assess relative intensity. A linear range of intensity was demonstrated among serial dilution of a synthetic mouse proinsulin I cRNA. Comparison of the cRNA standards with mouse total RNA hybridization allowed an estimation of proinsulin mRNA by weight.

\section{Statistical analysis}

The SKUMIX model: Consider any quantitative trait, $X$ (such as glucose levels) which is influenced by a single major locus with two alleles, $\mathrm{A}$ and $\mathrm{a}$. We denote the mean value of the trait for each of the three possible genotypes $\mathrm{AA}, \mathrm{Aa}$ and aa, by $\mu_{\mathrm{AA}}, \mu_{\mathrm{Aa}}$, and $\mu_{\mathrm{aa}}$, respectively. Assume that there is a random variable, $\xi$, which is normally distributed with mean 0 and variance $E$ so that for each individual with genotype $\mathrm{G}$,

$X=\mu_{G}+\xi$.

Under this model, the distribution of $\mathrm{X}$ in a population will be a mixture of three normal distributions, one for each genotype, with some overall mean, $\mu$. If the probability of having allele $a$ is $q$, then the probability of having genotypes $A A, A a$, and $a a$, are $(1-q)^{2}, 2 q(1-q)$, and $\mathrm{q}^{2}$, respectively, which correspond to the areas under the three component distributions. Since the relative distances between genotypic means are what are important here, it is convenient to reformulate the model in terms of parameters $t$ and $d$, such that

$\mu_{\mathrm{aa}}=\mu_{\mathrm{AA}}+\mathrm{t}$, and $\mu_{\mathrm{Aa}}=\mu_{\mathrm{AA}}+\mathrm{dt}$.

If there is a "single major gene effect", then the commingled distribution at the population level will be non-normal, have non-zero higher moments and in general be skewed, as $\mathrm{t}$ (and/or d) will be non-zero.

To add robustness to the model and to afford some protection against non-genetic sources of skewness, MacLean et al. [13] suggest using a power transformation of $X$. Under this approach, the commingling analysis is performed on the transformed scale, $\mathrm{Y}$, where for constants $\mathrm{r}$ and $\mathrm{p}$

$Y= \begin{cases}\frac{r}{p}\left[\left(\frac{X}{r}+1\right) p^{-1}\right] & \text { for } p \neq 0 \\ r \ln \frac{X}{r}+1 & \text { for } p=0\end{cases}$

$\mathrm{p} \rightarrow 0$

(Note that this is a continuous function for all $p$, since the lim of the first line in the definition of $\mathrm{Y}$ is the second line.) Therefore, the full three component model has 7 parameters: the overall mean, $\mu$; the within component variance, $\mathrm{E}$; the probability of having the a allele, $\mathrm{q}$; the distances between genotypic means, as governed by $t$ and $d$, and the skewness transformation parameters, $p$ and $r$. In our experi-

Table 1. Fed plasma glucoses (PG), fasted plasma glucose, fed plasma insulin, pancreatic insulin and proinsulin (PI) mRNA at 14 weeks of age

\begin{tabular}{lcccc}
\hline & $B L / K s[d b / d b]$ & \multicolumn{2}{c}{ Backcross $[\mathrm{db} / \mathrm{db}]$} \\
\hline $\begin{array}{l}\text { Fed PG } \\
(\mathrm{mmol} / \mathrm{l})\end{array}$ & $34.1 \pm 0.7^{\mathrm{a}}$ & $(12)$ & $31.4 \pm 0.6$ & $(31)$ \\
$\begin{array}{l}\text { Fasted PG } \\
\text { (mmol/1) }\end{array}$ & $25.6 \pm 0.8^{\mathrm{a}, \mathrm{c}}$ & $(12)$ & $21.6 \pm 0.8$ & $(31)$ \\
$\begin{array}{l}\text { Fed plasma } \\
\text { insulin (ng/ml) }\end{array}$ & $8.0 \pm 1.4^{\mathrm{a}, \mathrm{d}}$ & $(12)$ & $15.8 \pm 1.9$ \\
$\begin{array}{l}\text { Pancreatic insulin } \\
\text { (mg/pancreas) }\end{array}$ & $2.7 \pm 0.5^{\mathrm{a}, \mathrm{d}}$ & $(12)$ & $6.1 \pm 1.1$ & \\
$\begin{array}{l}\text { PI mRNA } \\
\text { (ng/pancreas) }\end{array}$ & $2.7 \pm 0.4^{\mathrm{b}, \mathrm{d}}$ & $(12)$ & $7.1 \pm 1.0$ & $(31)$ \\
\hline
\end{tabular}

Each value indicates mean \pm SEM. Number of mice are in parentheses. ${ }^{\mathrm{a}} p<0.01$ and ${ }^{\mathrm{b}} p<0.001$ vs Backcross mice for $\mathrm{t}$-test. ${ }^{\mathrm{c}} p<0.05$ and ${ }^{d} p<0.01$ vs Backcross mice for variance test 

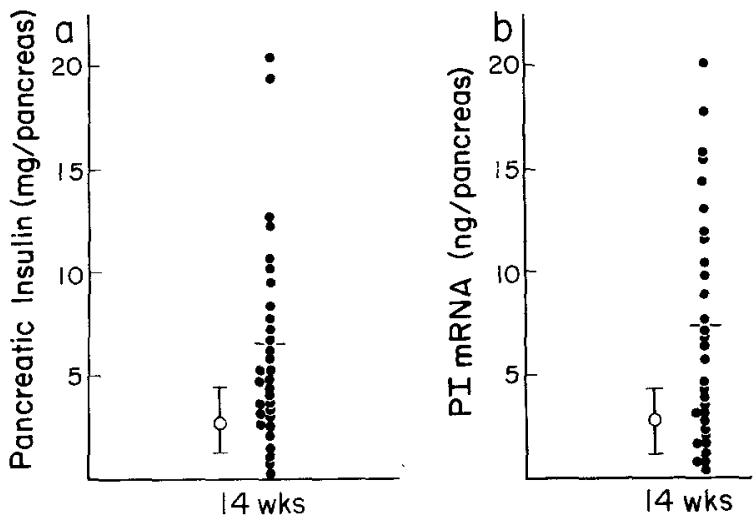

Fig.3. Pancreatic insulin (a) and proinsulin (PI) mRNA (b) was determined in $d b / d b$ mice $(n=31)$ at 14 weeks of age (closed circles) and compared to that in $d b / d b$ mice of the $\mathrm{BL} / \mathrm{Ks}$ parental strain $(n=12$, $X \pm S . D$., open circles), at the same age. The means of values mean in backcrossed mice at 14 weeks of age are represented by the dotted horizontal lines

ment one homozygous distribution is missing by design, but the same model may be used in this case by simply fixing $d=0$, so that only two commingled distributions remain. The model may be fit to the data by the method of maximum likelihood, and nested submodels tested through the likelihood ratio criteria. The data were analysed using this model as implemented in the FORTRAN program SKUMIX [13, 14].

\section{Results}

\section{Body weight, plasma glucose, and insulin of the backcrossed $d b / d b$ mice}

$\mathrm{F}_{1}$ hybrid female $(\mathrm{db} /+$ and $+/+)$ mice from $\mathrm{BL} / \mathrm{Ks}$ $(d b /+)$ and $129 / \mathbf{J}(+/+)$ parents were backcrossed to $\mathrm{BL} / \mathrm{Ks}(d b /+)$ male mice and a total of $252 \mathrm{BC}$ male mice were produced. At five weeks of age, 31 of the $\mathrm{BC}$ mice were identified as $d b / d b$ which were maintained until 14 weeks of age. The $d b / d b$ mice were readily distinguished from lean littermates $(d b /+$ or $+/+)$ by obesity and their characteristic shape at five weeks of age [1-3]; the body weight of the $\mathrm{BC}(d b / d b)$ was significantly higher than that of the lean littermates $(26.1 \pm 2.8 \mathrm{~g}$ and $21.3 \pm 1.0 \mathrm{~g}$ at 5 weeks of age, mean \pm SEM, $p<0.001$ ). The changes from 5-14 weeks of age in body weight, fed and fasted plasma glucose, and fed plasma insulin of the $\mathrm{BC}$ $(d b / d b)$ mice are shown in Figure 2. All BC $(d b / d b)$ mice showed an increase in body weight (Fig. 2 a). The mean body weight of the $\mathrm{BC}$ mice at 14 weeks of age was no different from that of $d b / d b$ mice of the $\mathrm{BL} / \mathrm{KsJ}$ parental strain.

Fed plasma glucose showed a marked elevation from 5 to 14 weeks of age (Fig. $2 \mathrm{~b}$ ); all $d b / d b$ BC became diabetic at 14 weeks of age with fed plasma glucose concentrations $>22 \mathrm{mmol} / 1$. The mean value of the $\mathrm{BC} d b / d b$ mice, however, was lower than that of the $\mathrm{BL} / \mathrm{Ks}(d b / d b)$ mice (Table $1, p<0.01)$.

The fasted plasma glucose and the fed plasma insulin concentrations at 10 or 14 weeks of age ranged in a continuum of values (Fig. $2 \mathrm{c}$ and $2 \mathrm{~d}$ ). The fasted plasma glucose at 14 weeks ranged from $13.9 \mathrm{mmol} / 1$ to $30.5 \mathrm{mmol} / 1$. Some $\mathrm{BC}$ mice were still markedly hyperinsulinaemic relative to the $\mathrm{BL} / \mathrm{Ks}$ parental strain at 14 weeks. The mean fasted plasma glucose was significantly lower and the mean fed plasma insulin significantly higher in $\mathrm{BC}(d b / d b)$ mice compared to that of the $\mathrm{BL} / \mathrm{Ks}(d b / d b)$ parental mice (Table $1, p<0.01$ for the fasted plasma glucose, and $p<0.01$ for fed plasma insulin).

Table 2. SKUMIX Analysis

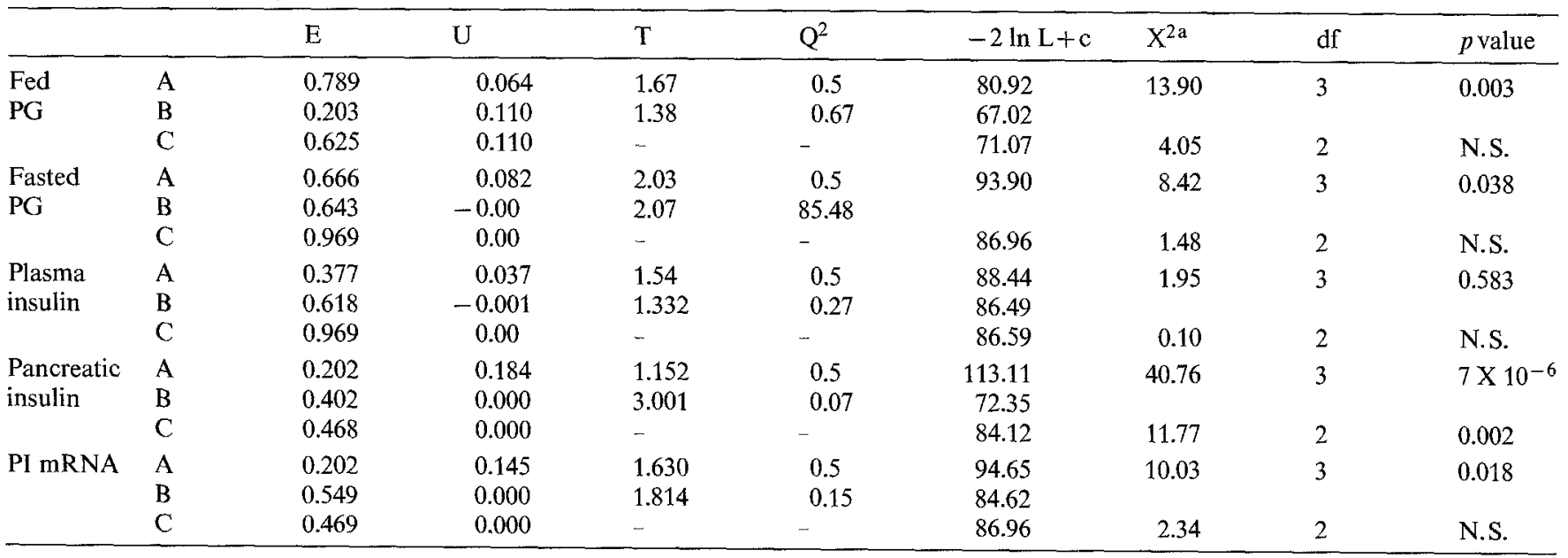

A general transformation power (P) which allows that some levels of skewness could not be differentiated from 1 (normal distribution). A: Parameters were fitted by the method of maximum likelihood for the expected single gene model ( 2 distributions) using information from the $\mathrm{BL} / \mathrm{KsJ}(d b / d b)$ parental strain. B: Parameters for the general model (2 distributions) estimating the backcross $(d b / d b)$ mice data alone. C: Parameters for a polygenic model (unimodal distribution). ${ }^{a} \mathrm{X}^{2}=$ difference between $\mathrm{A}(-2 \ln \mathrm{L}+\mathrm{c})$ and $\mathrm{B}(-2 \ln \mathrm{L}+\mathrm{c})$, or $\mathrm{B}(-2 \ln \mathrm{L}+\mathrm{c})$ and $\mathrm{C}$ $(-2 \ln \mathrm{L}+\mathrm{c})$

$\mathrm{PG}=$ plasma glucose 
Pancreatic insulin and proinsulin $m R N A$ of the backcross mice ( $d b / d b)$

The $\mathrm{BC}(d b / d b)$ mice were killed at 14 weeks, since a previous study [9] demonstrated a severe reduction in proinsulin mRNA in $\mathrm{BL} / \mathrm{Ks}(d b / d b)$ mice at 12 weeks of age, and the diabetes was so severe that some of the mice died. As shown in Figure 3 a, pancreatic insulin of the $\mathrm{BC}(d b / d b)$ mice at 14 weeks ranged in a continuum of values. Total pancreatic proinsulin mRNA content in each $d b / d b$ mouse also ranged widely from $0.5 \mathrm{ng}-$ $20 \mathrm{ng}$ (Fig. 1 and $3 \mathrm{~b}$ ). A considerable number of mice showed a markedly higher insulin value or proinsulin mRNA content compared with that of $d b / d b$ mice of the parental $\mathrm{BL} / \mathrm{Ks}$ strain.

\section{Estimation of the number of the genes determining the expression of diabetes}

In an attempt to use all of the information available in the experiment, the $\mathrm{BC} d b / d b$ data was tested to determine whether it was significantly better explained as a bimodal mixture of two distributions (as expected there was a single gene control) or whether a single, unimodal, possibly skewed distribution would fit the data better (as expected if the phenotype were under polygenic control or a single dominant gene). The program used was SKUMIX (see Methods), and the results of this analysis are shown in Table 2 and Figure 4. Five parameters are fit by the method of maximum likelihood: the overall mean $(\mathrm{U})$ of the mixed distribution, the variance $(\mathrm{E})$ within each component distribution, the distance $(\mathrm{T})$ between the means of the two distributions, the proportion of data in the rightmost distribution $\left(\mathrm{Q}^{2}\right)$, and a power transformation parameter $(\mathrm{P})$ which allows some levels of skewness. Finally for each model, -2 times the log-likelihood $(-2 \ln \mathrm{L}+\mathrm{c})$ is given, and by the likelihood ratio test we can contrast nested hypothesis. There are two major hypotheses to test.

The first test is whether two distributions fit the data significantly better than a single distribution. Rejection of a single distribution would be evidence against polygenic (and/or a dominant major gene) control. The second test is whether the parameters of two distributions are consistent with that predicted under a single gene model. Rejection here would argue against just one other locus besides the $d b$ locus. For the latter test, there are two approaches which could be taken. First, any information on the $\mathrm{BL} / \mathrm{Ks}(d b / d b)$ mice can be ignored, and the distribution of the phenotype in the backcross mice alone simply used. In that case, if there is only one more locus, the two distributions would have equal proportions, so that $\mathrm{Q}^{2}=1 / 2$. A two-distributional model with $\mathrm{Q}^{2}$ fixed to 0.5 could then be tested, against the alternative of a general two distribution one. This would provide a $X^{2}$ with one degree of

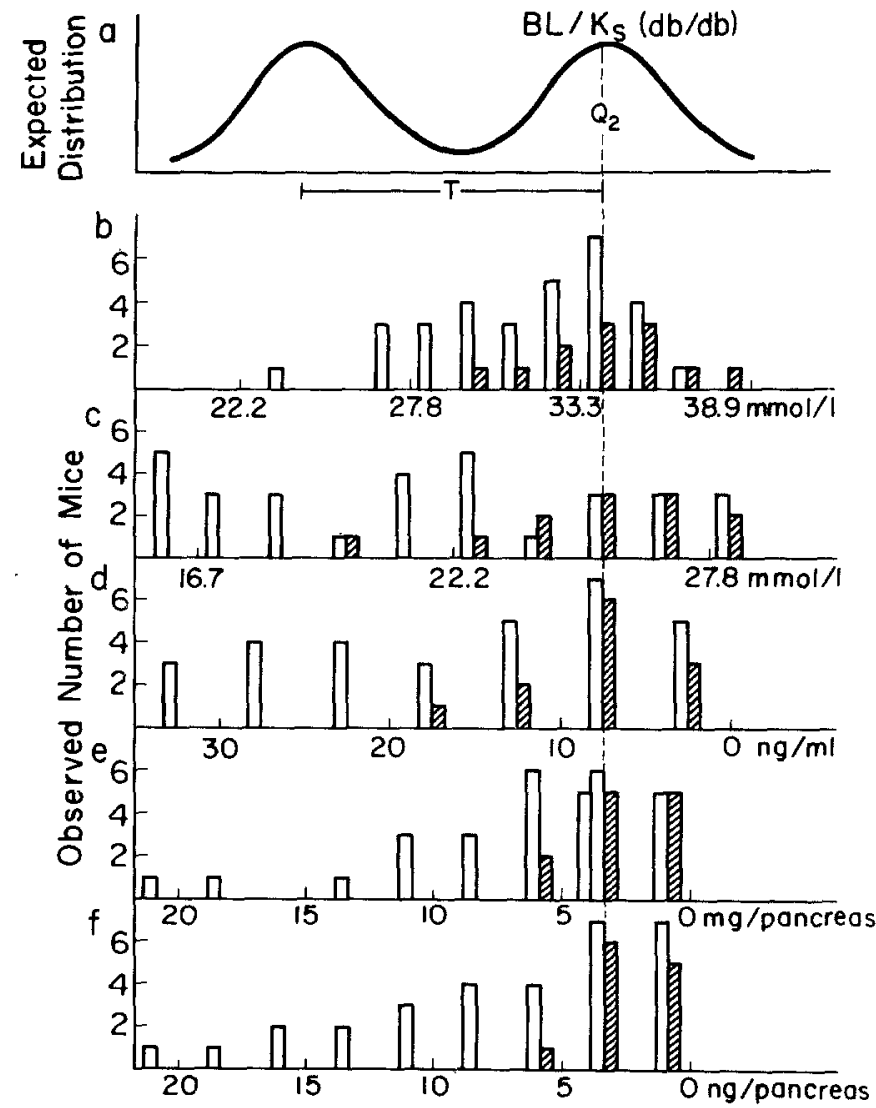

Fig.4. The expected distribution (a) predicted from the SKUMIX analysis (Table 2), and the observed distributions of fed plasma glucose (b), fasted plasma glucose (c), fed plasma insulin (d), pancreatic insulin (e), and proinsulin mRNA (f) in $d b / d b$ mice of the parental $\mathrm{BL} / \mathrm{Ks}$ strain (hatched bars) compared to that in the $d b / d b \mathrm{BC}$ mice (open bars). For each histogram the dotted vertical line represents the median value of $d b / d b$ mice of the parental $\mathrm{BL} / \mathrm{Ks}$ strain

freedom. On the other hand, the $\mathrm{BL} / \mathrm{Ks}(d b / d b)$ distribution could be used as well. If the distribution of the $\mathrm{BC}(d b / d b)$ mice is standardised to mean 0 and variance 1 , then since the overall mean is the sum of the individual distribution means weighted by the proportion of area under each curve, under a single gene model, $0=\left(\mu_{1}+\mu_{2}\right) / 2$, so that $\mu_{1}=\mu_{2}$. If the BL/Ks $(d b / d b)$ data is standardized to this same mean and variance, then the expected distance between the two means of the backcross $(d b / d b)$ data is twice the $\mathrm{BL} / \mathrm{Ks}(d b / d b)$ mean. For that matter, the variance within each of the component distributions for the $\mathrm{BC}(d b / d b)$ should be the same as the variance of the BL/Ks $(d b / d b)$ on this scale (Fig. 4a). Table 2 shows SKUMIX parameters in the presence of information on the BL/Ks $(d b / d b)$. A two-distributional model of each phenotype was rejected with a high probability except for the phenotype for plasma insulin level, regardless of the presence or absence of the information for the BL/Ks $(d b / d b)$ data (compare lines A and B, Table 2). On the other hand, a single distribution of all phenotypes including plasma insulin in the $\mathrm{BC}(d b / d b)$ mice could not be rejected (line $\mathrm{C}$, Table 2). These results provide strong evidence 

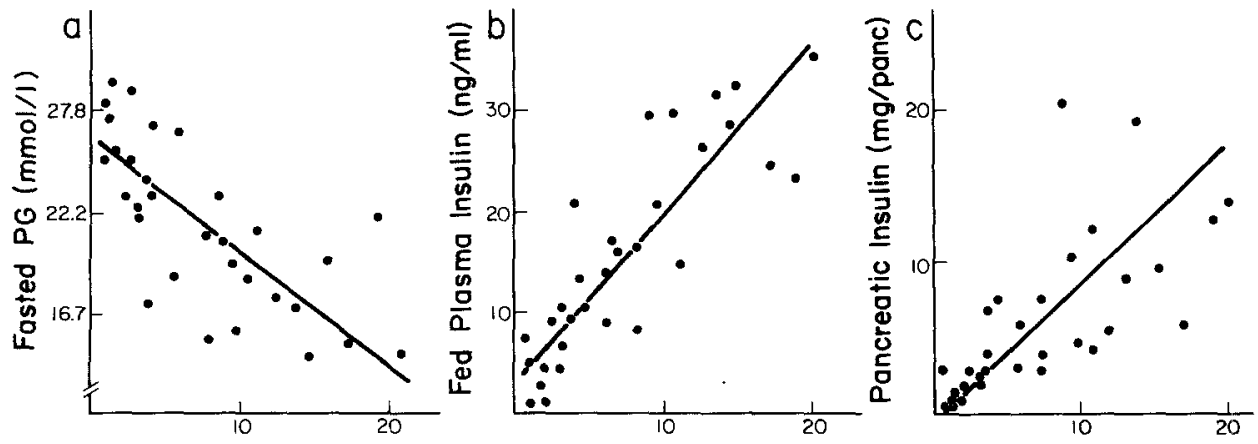

Fig.5. Correlation between pancreatic proinsulin (PI) mRNA and fasted plasma glucose (a), fed plasma insulin (b), and pancreatic insulin (c) in $31 \mathrm{BC} d b / d b$ mice at 14 weeks of age

PI mRNA (ng/pancreas)

to support the hypothesis of control by multiple genes or by a dominant single major gene. If a single dominant gene determined the phenotypes observed, distribution of each phenotype in the $\mathrm{BC}(d b / d b)$ mice must be consistent with that in the $\mathrm{BL} / \mathrm{Ks}(d b / d b)$ mice. As shown in Figure 4 and Table 1, however, the distribution pattern of each phenotype in the $\mathrm{BC}$ mice was significantly different from that in $d b / d b$ mice of the $\mathrm{BL} / \mathrm{Ks}$ parental strain, rejecting a single dominant major gene hypothesis.

Our results concluded that the diabetes phenotype associated with this $d b$ mutation is under polygenic control in the $\mathrm{BL} / \mathrm{Ks}$ mice. In addition, a marked hyperglycaemia ( $>22 \mathrm{mmol} / \mathrm{l})$ in all $\mathrm{BC}(d b / d b)$ mice in the fed state also suggested the presence of a dominant factor(s) in the BL/KsJ background.

\section{Discussion}

This study looked at the expression of diabetes induced by the $d b$ mutation after generating $\mathrm{F}_{1}$ hybrid mice from a diabetes susceptible (BL/Ks) and diabetes resistant $(129 / J)$ strain, and backcrossing the $F_{1}$ hybrids to the diabetes susceptible strain. The recent finding of high blood glucose in all $F_{1}$ and $F_{2}$ progeny of $B L / K s$ and $\mathrm{BL} / 6$ crosses (12) suggested that either the genes controlling diabetes susceptibility in the $\mathrm{BL} / \mathrm{Ks}$ strain had become dominant to those in $\mathrm{BL} / 6$ mice, or that the $\mathrm{BL} / 6$ strain had become less diabetes resistant. We had recently observed higher blood glucose in $\mathrm{BL} / 6 \mathrm{db} / \mathrm{db}$ males at one month of age (indistinguishable from that of $\mathrm{BL} / \mathrm{Ks} d b / d b$ males) than previously reported [15], further suggesting that the $\mathrm{BL} / 6$ strain had become less diabetes resistant. The effect of the $d b$ mutation in $129 / \mathrm{J}$ mice has been extensively evaluated $[7,8]$. The $129 / \mathrm{J} d b / d b$ males were found to be hyperphagic, obese, and severely hyperinsulinaemic, with plasma glucose peaking at 2-4 months of age at approximately $15 \mathrm{mmol} / \mathrm{l}$. Histologic examination of pancreata from the $129 / \mathrm{J} d b / d b$ mice revealed massive hyperplasia of pancreatic B-cells, but no B-cell necrosis or atrophy. The degree of hyperplasia in the islets was more extensive than had been observed in other $d b$ carrying stocks, and this strain appeared to be well suited for evaluating the diabetes susceptible background modifiers in the $\mathrm{BL} / \mathrm{Ks}$ strain.

For genetic analysis, knowing that the $d b$ mutation is necessary, but not sufficient, to induce obesity and diabetes, we examined the possibility of exactly one other modifying gene in linkage disequilibrium with the $d b$ locus which works together to develop diabetes. Now each parental strain is assumed to be homozygous at each locus. If the $\mathrm{BL} / \mathrm{Ks}(d b /+)$ is "aa" at this other locus, then the $129 / \mathrm{J}(+/+)$ must be "AA". The $\mathrm{F}_{1}$ , generation are half $d b /+$ and half $+/+$, and all heterozygous at the A locus. Backcrossing the female $F_{1}$ with the male $\mathrm{BL} / \mathrm{Ks}(d b /+)$, and selecting out the $\mathrm{BA}$ $d b / d b$, we expect half to be Aa and half to be aa. If "a" is dominant for the trait of interest, we would not be able to tell phenotypically between the genotypes Aa and aa, and there would be a single unimodal distribution. If "a" is recessive, or at least far from dominant, then this would produce a mixture of two distributions, creating a bimodal distribution of the phenotype in the $31 d b / d b$ backcross mice with one mode near each parental mean. At the other extreme, if diabetes is under polygenic control, then in this $\mathrm{BC} d b / d b$ progeny there would be a single unimodal distribution for the phenotype as well as in a single dominant gene hypothesis. In a classic $\mathrm{BC}$ experiment, where we look for a single gene only, we would also have the phenotype measured independently on the parental strains, which under the single gene model would have the same relevant genotypes. We could use this independent information in addition to the bimodality in the $\mathrm{BC}$ mice data to test the single hypothesis. In this experiment, however, since we are dealing with the $d b$ locus as well as the A locus, we would need to have information on the $d b / d b$-aa and $d b / d b$-Aa genotypes. The BL/Ks strain homozygous for $d b$ locus exists and is $d b / d b$-aa genotype. The $d b$ mutation is no longer maintained on the $129 / \mathrm{J}$ background, however, so it was necessary to breed $\mathrm{BL} / \mathrm{Ks}$ $(d b /+)$ with $129 / J(+/+)$ mice, and so no $F_{1}$ generation homozygous for the $d b$ mutation $(d b / d b-\mathrm{Aa})$ mice could be obtained. Therefore, we can only get independent information on the phenotype distribution of one of the two relevant genotypes. Even in the absence 
of $\mathrm{F}_{1} d b / d b$ data however, we have tested whether two distributions fit the data significantly better than a single distribution for the various parameters measured in the $\mathrm{BC}$ mice (Table 2). Either using the distribution of the parameters in $d b / d b$ mice of the parental strain $\mathrm{BL} / \mathrm{Ks}$, or simply using the distribution of the phenotype in the $\mathrm{BC}$ mice alone, all of the parameters fit a unimodal distribution better than a bimodal, and thus the evidence strongly favours multiple genes involved in diabetes susceptibility.

The genes involved in diabetes susceptibility in $\mathrm{BL} / \mathrm{Ks}$ mice are unknown. Recently responses to dexamethasone administration in $d b / d b \mathrm{BL} / \mathrm{Ks}$ and $\mathrm{BL} / 6$ mice [15] suggested greater insulin resistance in $\mathrm{BL} / \mathrm{Ks}$ mice, In addition, dexamethasone failed to induce proinsulin mRNA in the $\mathrm{BL} / \mathrm{Ks} d b / d b$ mice suggesting that a limitation of insulin production at the level of insulin synthesis might explain the enhanced diabetes susceptibility of this strain. Type $\mathrm{C}$ retrovirus induction in pancreatic B-cells of some $d b$-sensitive strains has been noted $[16,17]$, while other studies have suggested differences in immune responsiveness [18-20]. One study noted a limited capacity for B-cell DNA replication [21]. Finally, when Leiter crossed obesity-induced diabetes susceptible $\mathrm{BL} / \mathrm{Ks}$ mice with NOD mice which develop spontaneous autoimmune diabetes, none of the offspring developed diabetes, thus indicating that different genes are responsible for the two types of diabetes [22].

Background modifying genes in the $d b$ model have been shown to be strongly gender related, as the diabetes syndrome occurs only in males in some $d b$ congenic stocks, and can be prevented by female sex steroids [7, 22]. Leiter has accumulated evidence suggesting that the sex differences are produced by sexlinked differences in the metabolism of androgens and their precursors in these inbred strains. The $\mathrm{BL} / \mathrm{Ks}$ mice appear to be more sensitive than the $\mathrm{BL} / 6$ mice to endogenous androgens. The current study avoided this gender related genetic contribution by evaluating only male $\mathrm{BC}$ mice with $\mathrm{Y}$-chromosomes from the $\mathrm{BL} / \mathrm{Ks}$ parental strain.

As seen in the current analysis, previous studies had suggested that multiple genes determine expression of diabetes in $\mathrm{BL} / \mathrm{Ks}$ mice with obesity induced by the $d b$ mutation. The initial study of $\mathrm{BL} / \mathrm{Ks}$ and $\mathrm{BL} / 6 \mathrm{BC}$ mice [11] failed to show a clear segregation of glucose, insulin, or islet histology into $\mathrm{F}_{1}$-like and $\mathrm{BL} / \mathrm{Ks}$-like, but observations were pooled on 10 male and 10 female $\mathrm{BC}$ mice. In the more recent study [12] there was no segregation of fed plasma glucose in the $\mathrm{F}_{2}$ generation, and diabetes susceptible genes in $\mathrm{BL} / \mathrm{Ks}$ mice were dominant to resistance genes in $\mathrm{BL} / 6$ mice. The current analysis in $\mathrm{BL} / \mathrm{Ks}$ and $129 / \mathrm{J}$ mice clearly indicated that diabetes susceptible genes in $\mathrm{BL} / \mathrm{Ks}$ mice are dominant to resistant genes in the $129 / \mathrm{J}$ strain as well. The current study further extends the previous observations. While fed plasma glucoses in all of the BC animals were clear- ly in the diabetic range $(>22 \mathrm{mmol} / \mathrm{l})$, the severity of diabetes in these mice varied, as determined by the spectrum of fasting plasma glucose, fed plasma insulin, pancreatic insulin content, and proinsulin mRNA. That proinsulin mRNA content, previously shown to reflect the degree of insulin synthesis in vivo [23], is a good indicator of the severity of diabetes and degree of islet dysfunction, is reflected in the inverse correlation (Fig. $5 \mathrm{~A}$ ) between proinsulin mRNA and fasting plasma glucose $(r=0.69, p<0.001)$, and the direct correlation (Fig. $5 \mathrm{~b}$ ) between proinsulin mRNA and fed plasma insulin ( $r=0.86, p<0.001)$, and (Fig. $5 \mathrm{c})$ pancreatic insulin content $(r=0.61, p<0.01)$. Using proinsulin mRNA as one measure of functional B-cell mass, the distribution of values in the $\mathrm{BC}$ mice could not be accounted for by a single gene controlling islet destruction.

It was initially anticipated that if a single gene were responsible for severe islet destruction, one-half of the $B C$ mice would develop low proinsulin mRNA levels like the $\mathrm{BL} / \mathrm{Ks}$ parent, and one-half would be resistant to islet destruction. We could then look for linkage of the locus responsible for islet necrosis in the $\mathrm{BC}$ mice and attempt to define the locus by the process of reverse genetics. Finding that allelic differences at more than a single locus are responsible for this islet destruction makes this type of analysis far more difficult. The implications of these findings in closely related species of mice, for analysis of genetic susceptibility to obesity-induced diabetes in man, is obvious.

Acknowledgements. We thank Ms. Cris Reents for her technical assistance, and Ms. Jeannie Wokurka for help in preparation of the manuscript. We also thank Drs. Doug Coleman and Ed Leiter for helpful discussions and data prior to publication. This work was supported by Juvenile Diabetes Foundation Grant 386311 and by NIH Grants AM16746 and GM28719.

\section{References}

1. Hummel KP, Dickie MM, Coleman DL (1966) Diabetes, a new mutation in the mouse. Science 153: 1127-1128

2. Coleman DL, Hummel KP (1967) Studies with the mutation, diabetes, in the mouse. Diabetologia 3: 328-348

3. Hummel KP, Coleman DL, Lane PW (1972) The influence of genetic background on expression of mutations at the diabetes locus in the mouse. I. C57BL/KsJ and $\mathrm{C} 57 \mathrm{BL} / 6 \mathrm{~J}$ strains. Biochem Genetics 7: 1-13

4. Coleman DL (1978) Obese and diabetes: Two mutant genes causing diabetes-obesity syndromes in mice. Diabetologia 14: 141-148

5. Leiter EH (1981) The influence of genetic background on expression of mutations at the diabetes locus in the mouse. IV. Male lethal syndrome in CBA/Lt mice. Diabetes 30: 1035-1044

6. Leiter EH, Coleman DL, Eisenstein AB, Strack I (1981) Dietary control of pathogenesis in $\mathrm{C} 57 \mathrm{BL} / \mathrm{KsJ}-d b / d b$ diabetes mice. Metabolism 30: 554-562

7. Leiter EH, Coleman DL, Hummel KP (1981) The influence of genetic background on the expression of mutations at the diabetes locus in the mouse. III. Effect of $\mathrm{H}-2$ haplotype and sex. Diabetes 30: $1029-1034$

8. Leiter EH, Coleman DL, Eisenstein AB, Strack I (1980) A new mutation $\left(d b^{\mathrm{dJ}}\right)$ at the diabetes locus in strain $129 / \mathrm{J}$ mice. Diabetologia 19: 58-65 
9. Orland MJ, Permutt MA (1987) Quantitative analysis of pancreatic proinsulin mRNA in genetically diabetic $(d b / d b)$ mice. Diabetes 37: 341-347

10. Hummel KP, Coleman DL, Lane PW (1972) The influence of genetic background on expression of mutations at the diabetes locus in the mouse. I. C57BL/KsJ and $\mathrm{C} 57 \mathrm{BL} / 6 \mathrm{~J}$ strains. Biochem Genetics 7: 1-13

11. Coleman DL, Hummel KP (1975) Influence of genetic background on the expression of mutations at the diabetes locus in the mouse. II. Studies on background modifiers. Israel J Med Sci 11: $708-713$

12. Leiter EH, Le PH, Coleman DL (1987) Susceptibility to $d b$ gene and streptozotocin-induced diabetes in C57BL mice: control by gender-associated, MHC-unlinked traits. Immunogenetics 26: 6-13

13. MacLean CJ, Morton NE, Elston RC, Yee S (1976) Skewness in commingled distributions. Biometrics 32: 695

14. Morton NE, Rao DC, Lalouel JM (1982) Methods in Genetic Epidemiology. Karger, Basle, pp 18-23

15. Orland MJ, Permutt MA (1987) Genetic susceptibility to diabetes in inbred strains of mice: measurements of proinsulin mRNA and response to dexamethasone. Diabetologia 30:934-939

16. Leiter EH (1985) Type C retrovirus production by pancreatic beta cells. Association with accelerated pathogenesis in $\mathrm{C} 3 \mathrm{H}-d b / d b$ ("diabetes") mice. Am J Pathol 119: 22-32

17. Leiter EH, Fewell JW, Ruff EI (1986) Glucose induces intracisternal type A retroviral gene transcription and translation in pancreatic beta cells. J Exp Med 163: 87-100

18. Dardenne M, Savino W, Bach J-F (1984) Autoimmune mice develop antibodies to thymic hormone: Production of anti-thymulin monoclonal autoantibodies from diabetic $(d b / d b)$ and $\mathrm{B} / \mathrm{W}$ mice. J Immunol 133: 740-743
19. Meade CJ, Brandon DR, Smith W, Simmonds RG, Harris S, Sowter C (1981) The relationship between hyperglycemia and renal immune complex deposition in mice with inherited diabetes. Clin Exp Immunol 43: 109-120

20. Fernandes G, Handwerger BS, Yunis EJ, Brown DM (1978) Immune response in the mutant diabetic $\mathrm{C} 57 \mathrm{BL} / \mathrm{Ks}-d b+$ mouse. Discrepancies between in vitro and in vivo immunological assays. J Clin Invest 61 : 243-250

21. Swenne I, Andersson A (1984) Effect of genetic background on the capacity for islet cell replication in mice. Diabetologia 27 : 464-467

22. Leiter EH, Prochazka M, Coleman DL, Serreze DV, Shultz LD (1986) Genetic factors predisposing to diabetes susceptibility in mice. In: Mollnar GD, Jaworski MA (eds) The Immunology of Diabetes Mellitus. Elsevier, Amsterdam, pp 29-36

23. Permutt MA, Kakita K, Malinas P, Karl I, Bonner-Weir GC, Giddings SJ (1984) An in vivo analysis of pancreatic protein and insulin biosynthesis in a rat model for non-insulin-dependent diabetes. J Clin Invest 73: 1-7

Received: 28 November 1988

and in revised form: 17 May 1989

Dr. M.A. Permutt

Metabolism Division

Washington University School of Medicine

660 South Euclid, Box 8127

St. Louis, MO 63110

USA 